\title{
The Fertilizer Industry in Brazil and the Assurance of Inputs for Biofuels Production: Prospective Scenarios after COVID-19
}

\author{
Pedro Igor Veillard Farias ${ }^{1,2, *} \mathbb{D}$, Estevão Freire ${ }^{1}{ }^{\mathbb{D}}$, Armando Lucas Cherem da Cunha ${ }^{1}$, \\ Raul José dos Santos Grumbach ${ }^{3}$ and Adelaide Maria de Souza Antunes 1,2 (D) \\ 1 Escola de Química, Universidade Federal do Rio de Janeiro (UFRJ), Rio de Janeiro 21949-900, Brazil; \\ estevao@eq.ufrj.br (E.F.); armando@eq.ufrj.br (A.L.C.d.C.); adelaide@eq.ufrj.br (A.M.d.S.A.) \\ 2 Instituto Nacional de Propriedade Industrial (INPI), Rio de Janeiro 20090-910, Brazil \\ 3 Brainstorming Assessoria de Planejamento e Inf., Rio de Janeiro 226310-00, Brazil; \\ raul@brainstorming.com.br \\ * Correspondence: pedro.veillard@eq.ufrj.br
}

Received: 11 August 2020; Accepted: 19 October 2020; Published: 26 October 2020

\begin{abstract}
Fertilizers are essential inputs for the agribusiness chain - they increase the productivity on available arable land and help to avoid changes in land use. Currently, Brazil is one of the largest consumers of fertilizers in the world but its imports of NPK fertilizers, as a percentage of its total consumption, have risen from 32\% in 1988 to $77 \%$ in 2018. Biofuels are relevant in the transport sector and the Brazilian government, after the Paris Agreement, created the National Biofuels Policy (Renovabio), which has as one of its goals to raise the participation of biofuels in the transport sector to $28.6 \%$ by 2028 . Soy, corn, and sugarcane (biofuels raw material) currently account for more than $70 \%$ of the consumption of NPK fertilizers in the country. Due to several reasons, in the last 10 years many local projects designed to fill the supply gap for fertilizers in Brazil have not been successful. The recent COVID-19 pandemic has raised questions about the reliability of fertilizer supply in global value chains. In this context, is Brazil's long-term biofuel market at risk after COVID-19? A total of 38 experts were consulted and four reference scenarios were developed. The article concluded that the Brazilian fertilizer industry must be prepared for a scenario of limited increase in demand on a global scale-strategic alliances may be forged to maintain existing installed capacity. Should the Brazilian government fail to provide any stimulus for the country's fertilizer industry, it is likely that by 2035, Brazil's biofuel industry sector would be overexposed to price volatility and availability on the global fertilizer market.
\end{abstract}

Keywords: agricultural inputs; biofuels; fertilizer; Brazil; prospective; COVID-19

\section{Introduction}

Agribusiness is a major driver of the Brazilian economy. In 2019, the Brazilian trade balance recorded a US $\$ 48$ billion surplus, $17.2 \%$ lower than the one recorded in 2018, and $28.3 \%$ lower than in 2017. However, in 2019 the agribusiness sector was responsible for a surplus of US\$ 83 billion. In other words, without agribusiness, Brazil would record recurring deficits in its trade balance [1]. Soy, corn, and sugarcane currently account for more than $60 \%$ of the gross value of agriculture (considering only crops) [2]. Brazil is the fourth largest consumer of fertilizers in the world, behind China, India, and the USA [3]. Agriculture plays an essential role in mitigating climate change: at least $40 \%$ of the world's soil is used as cropland or grassland and the use of fertilizers can contribute to soil carbon sequestration, increasing biomass productivity [4] and forestalling deforestation. Climatic impacts caused by agricultural intensification are preferable to those of a system with lower inputs and land 
expansion to meet global demand [5]. Consequently, crop nutrition plays a key role in the achieving of Goals 2 (Zero Hunger) and 13 (Climate Action) of the United Nations Sustainable Development Agenda [6].

The importance of renewable energy sources in Brazil has grown in recent years [7] —in 2018, these sources were responsible for $45.2 \%$ of domestic energy supply, with prominent roles for sugar cane products (17.4\%), hydraulic (12.6\%), firewood and charcoal (8.4\%) [8] — while, in the same year, the global average consumption of energy from renewable sources is estimated at $11 \%$ [9]. The importance of biofuels in the transport sector is relevant: ethanol accounted for $18.7 \%$ of the national demand for fuels, while biodiesel accounted for $4.3 \%$ in 2018 [8]. In 2019, these values corresponded to $20.6 \%$ and $4.5 \%$, respectively (preliminary data) [10]. The Brazilian government created the National Biofuels Policy (Renovabio), an instrument that aims to contribute to the achievement of the commitments assumed by Brazil in the Paris Agreement [11], which has as one of its goals to raise the participation of biofuels in the transport sector to $28.6 \%$ by 2028 [12].

Brazil currently imports most of the fertilizers it needs for its agricultural activity. In the last 30 years, its imports of NPK fertilizers, as a percentage of its total fertilizer consumption, have risen from $32 \%$ in 1988, to $50 \%$ in 1998 , to $68 \%$ in 2008 , and to $77 \%$ in 2018 [13]. In 2019, Brazil imported more than US $\$$ billion in fertilizers [14]. The development of the Brazilian fertilizer industry has been captained by state investment since the 1960s. In the 1990s, the sector was largely transferred to private companies [15].

With two world wars, The Great Depression, massive growth of state power, private institutions, and international organizations, as well as important changes in the field of scientific and philosophical knowledge, the twentieth century brought to light the need for new disciplines to improve the management of institutions, including consideration of the environment they were operating in [16]. There are several tools to perform a foresight exercise (scenarios, expert panels, essays, future workshops, literature review, morphological analysis, brainstorming, and others) [17]. However, prospective attitude (the move from foresight to strategic foresight) should aim to dominate the expected change and induce the desired change, by means of strategic planning [18], and scenarios can be useful: they are suitable for studying systems of high levels of complexity and uncertainty [19]. The NPK fertilizer industry interacts with several economic activities, such as agribusiness (food and energy), oil and gas $(\mathrm{O} \& \mathrm{G})$, the chemical industry, foreign trade and the mineral industry — which exacerbates its complexity and uncertainty. In the face of potential input shortages for the Brazilian biofuels value chain, prospective scenarios could prove effective in elucidating the long-term prospects for the NPK fertilizer industry.

This article aims to identify possible opportunities and challenges for the development of the fertilizer industry in Brazil using a prospective approach (Delphi Questionnaires, Probabilistic Scenarios, 2035 horizon).

\section{Methods}

The first phase of the scenarios approach applied in this article (Grumbach Method, see Figure 1) consists of delimiting the boundaries between the system and the environment: the system considers only the NPK basic fertilizer industry based in Brazil and the horizon is at 2035. The second phase of the methodology involved performing a strategic diagnosis in order to identify systematically possible relevant variables related to: market structure, the profile of organizations, their economic situation, the scale of plants, their investments, access to domestic and foreign markets, access to raw materials, access to technology, demand factors in Brazil and worldwide (market size, growth, foreign trade, trends, agribusiness), production factors (infrastructure, regulatory environmental regulation), business environment, access to credit, etc. Complementary to the method, raised variables were interrelated (identification of patterns of behavior and construction of a cause-effect map) in order to help the choice of definitive events (in phase 3 ). The second phase is briefly developed in Section 3 [20]. 


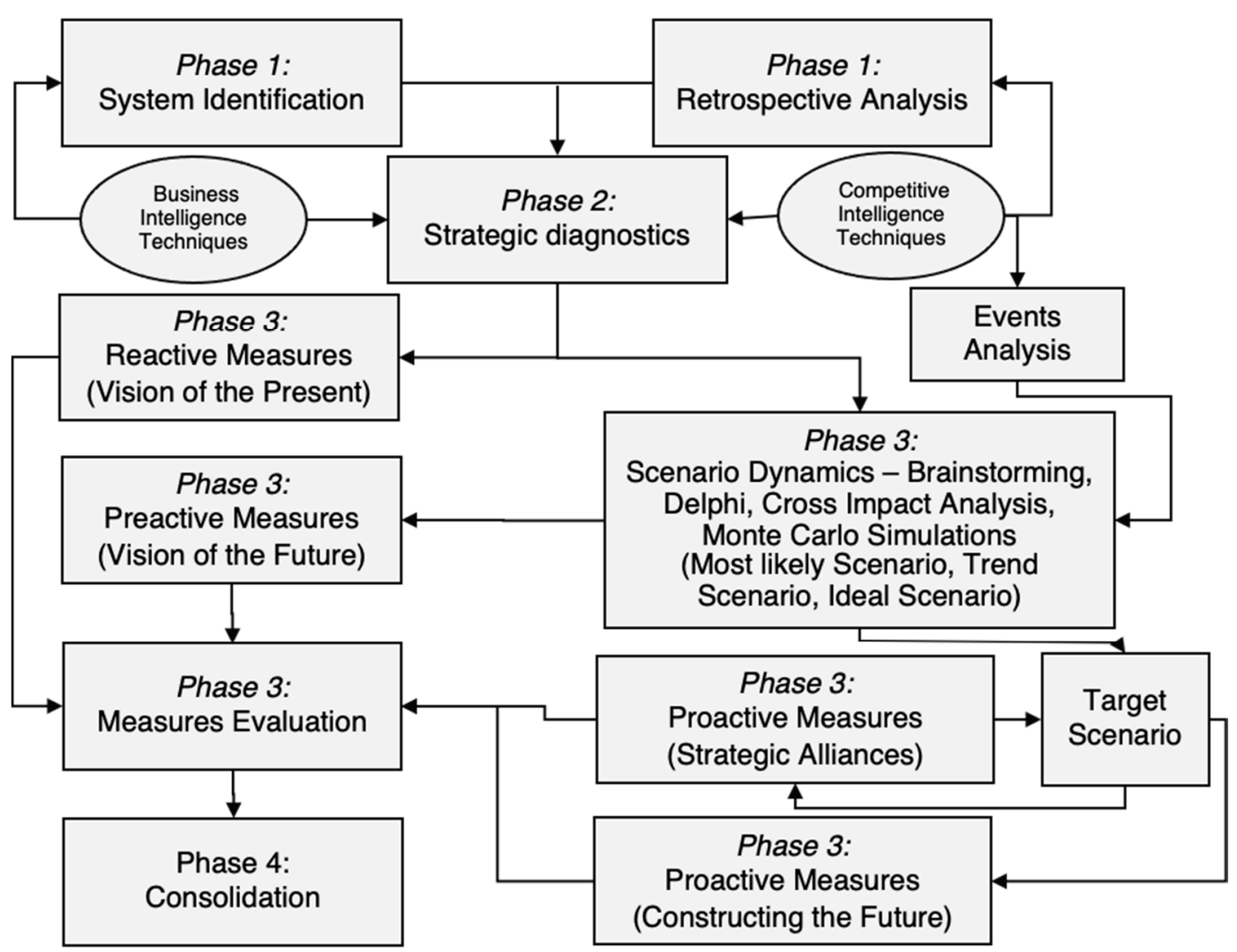

Figure 1. Prospective Scenarios approach proposed by Marcial and Grumbach (2008) [20].

The third phase of the methodology consisted of preparing the scenarios. Specific events had to be chosen to compose the scenarios [20]. These specific events were presented to experts via a Delphi Questionnaire-a traditional method of obtaining expert opinion consensus by subjecting them to questionnaires [21]. Scenarios were generated with statistical support combining Monte Carlo simulation and cross-impact matrix analysis. Of all the scenarios generated, three were highlighted: the most likely scenario, the trend scenario (or projective), and the ideal scenario. The preactive analysis aims to classify the events as a source of opportunity or a threat for this industry-it demonstrates for what this industry should be prepared for in the future. In addition, we built a proposal for an alternative future, the target scenario (proactive analysis) [20]. Using storytelling techniques is useful to describe the scenarios and their implications [22]. This analysis is presented in Section 4. The fourth and final phase comprises the consolidation of the prospective study (Section 5-Conclusions).

\section{Strategic Diagnosis}

\subsection{NPK Fertilizer Industry and Agribusiness Input}

Brazil is the second largest producer of biofuels in the world (22.4\% of world production in 2018), behind only the USA, with 39.9\% [9]. Soy, corn, and sugarcane currently account for more than 70\% of the consumption of NPK fertilizers in the country [13]. In 2019, more than $70 \%$ of the biodiesel produced in Brazil came from soybean oil. In the 2019/2020 harvest, it is estimated that $66 \%$ of the sugar cane produced will be destined to ethanol [23]. Brazilian corn, which was traditionally destined for the domestic market, after the technological development that allowed soy monoculture to transition into a rotational corn/soy system, has been gaining competitiveness [24]. While the production of corn ethanol in 2016 was nil, currently more than $6 \%$ of the national production is destined for ethanol production and there is a grain surplus of $30 \%$ to be exported [25]. The price of fertilizer inputs is relevant to price formation in the agricultural sector. In Brazil, there are soy farmers (Sorriso-Mato Grosso) who spend 
approximately $32 \%$ of the total cost of production on fertilizers [26], while corn production farmers (Primavera do Leste-Mato Grosso) would invest around 27\% [27]. In Penápolis (São Paulo), the cost of fertilizers for planting sugar cane represents $19 \%$ of the total production cost [28].

Between 2001 and 2008, the price of fertilizer commodities experienced higher growth rates than rice, corn or wheat [29] and the apparent consumption of Brazilian fertilizer reduced in 2004-2006 and 2007-2010 [30]. In 2013, there were several ongoing projects aiming to expand basic NPK fertilizer production capacity [31]. Even so, domestic production in 2020 is lower (Figure 2). Many of these ventures stalled due to regional factors, such as the political and economic crisis that hit Brazil in the 2010s, causing extreme uncertainty to the industry and keeping investments at bay.

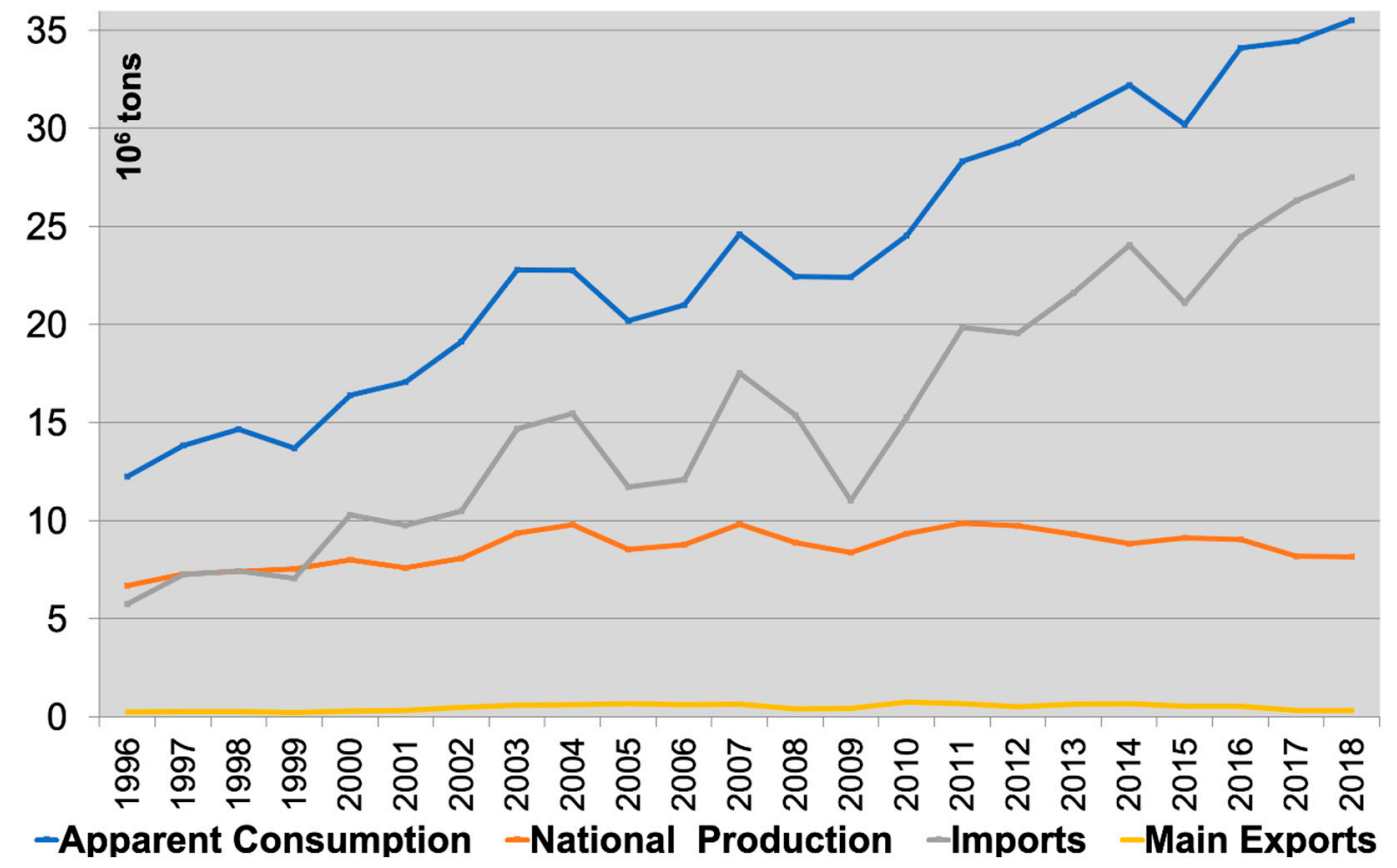

Figure 2. Brazilian fertilizer trade balance between 1996 and 2018 [13,30].

In a wider context, some other factors also contributed to the lack of attractiveness of these projects: persistent falling global prices of the main agricultural commodities (and considerable inventories); unfavorable climatic conditions in South and Southeast Asia, Latin America, and Africa [32]; slowing economic growth and environmental policies to increase the efficiency of fertilizer application in China [33]; exchange rate devaluations in countries like Turkey, India, and Pakistan [34]; the trade dispute between the USA and China; and the uncertainties surrounding the UK's exit from the European Union [35]; for the past 10 years, the world has experienced global growth rates below $4 \%$ per year and, in 2019, experienced the lowest growth rate since the 2008 crisis (estimated at 2.4\%) [36]. The COVID-19 pandemic will probably affect the global fertilizer industry in the short and medium term. In a global context, its demand-restricting effects will likely have a greater impact than those seen during the collapse of the USSR and during the global crisis of 2008. In addition to the effects arising from the difficulty of access to fertilizers, the volatility of oil prices, and the economic slowdown, with recession in certain key markets, the fertilizer industry will have to deal with widespread disruption of transportation, labor shortages, trade restrictions, evidence of a new swine fever, and new restrictions on maritime emissions [37]. China was the first country to suffer the consequences of the COVID-19 pandemic. The lockdown affected its imports of raw materials, production in fertilizer factories, the export of fertilizer products, and even domestic consumption. A comparable situation occurred in India and the USA. This scenario of reduced consumption caused a considerable drop in prices. Some products such as urea and potassium chloride have reached their 
lowest price in recent years. However, in Brazil this price drop has not been felt with the same intensity, since the country is heavily dependent on imports [38]. The recent events can benefit Brazilian agro exports-food safety can become one of the main points of cooperation between Brazil and China [39]. However, the biofuels industry probably will be negatively impacted due to low oil prices [23].

The Brazilian nitrogen fertilizer industry faces several local challenges. It is very common in Brazil for the industrial sector to acquire natural gas at prices above US\$13/mmBtu [40]. In comparison, some fertilizer companies in Russia have access to natural gas at around US\$3/mmBtu [41,42]. In the USA, the Henry-Hub Index experienced a downward trend in recent years, falling below US\$ 3/mmBtu [9], stimulated by the competitiveness of shale-gas [43]. In 2019, the Brazilian National Energy Policy Council established new guidelines in order to promote competition in the natural gas market [44] and the modernization of the natural gas regulatory framework is now under discussion in the National Congress [45]. The Brazilian phosphate and potash fertilizer industry also faces internal challenges. The mineral extraction stages face the same difficulties as most of the national mining industry, usually located in remote areas where the logistics structure still needs to be developed [46]. The phosphate deposits are predominantly of igneous origin, with low phosphate content [47]. In 2018, the company Vale chose to exit the fertilizer market, selling its phosphate and potassium assets to Mosaic Company and its nitrogen assets to Yara-increasing concentration in the global market [48]. There are also unexplored potash deposits in an area of extreme environmental and social sensitivity: the Amazon [49]. Furthermore, fertilizer producers claim that Brazilian laws do not guarantee tax isonomy between domestic and imported products-imported ones are tax exempt, while national production is charged in interstate operations [50].

\subsection{Variables Raised and Cause-Effect Map}

During the execution of the strategic diagnosis, the authors identified almost 100 variables (in a brainstorming session with experts) and the raised variables are interrelated in Figure 3A,B. This map enables a wide range of conclusions and it will be useful for choosing the definitive events.

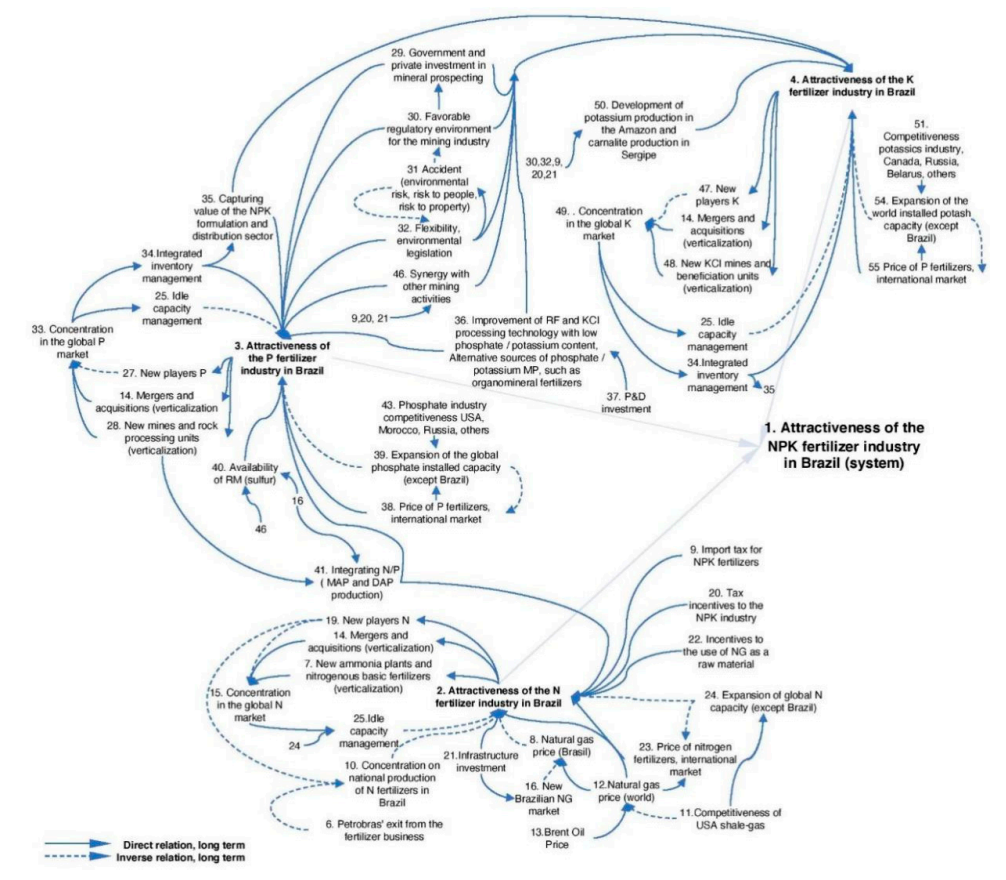

(A)

Figure 3. Cont. 


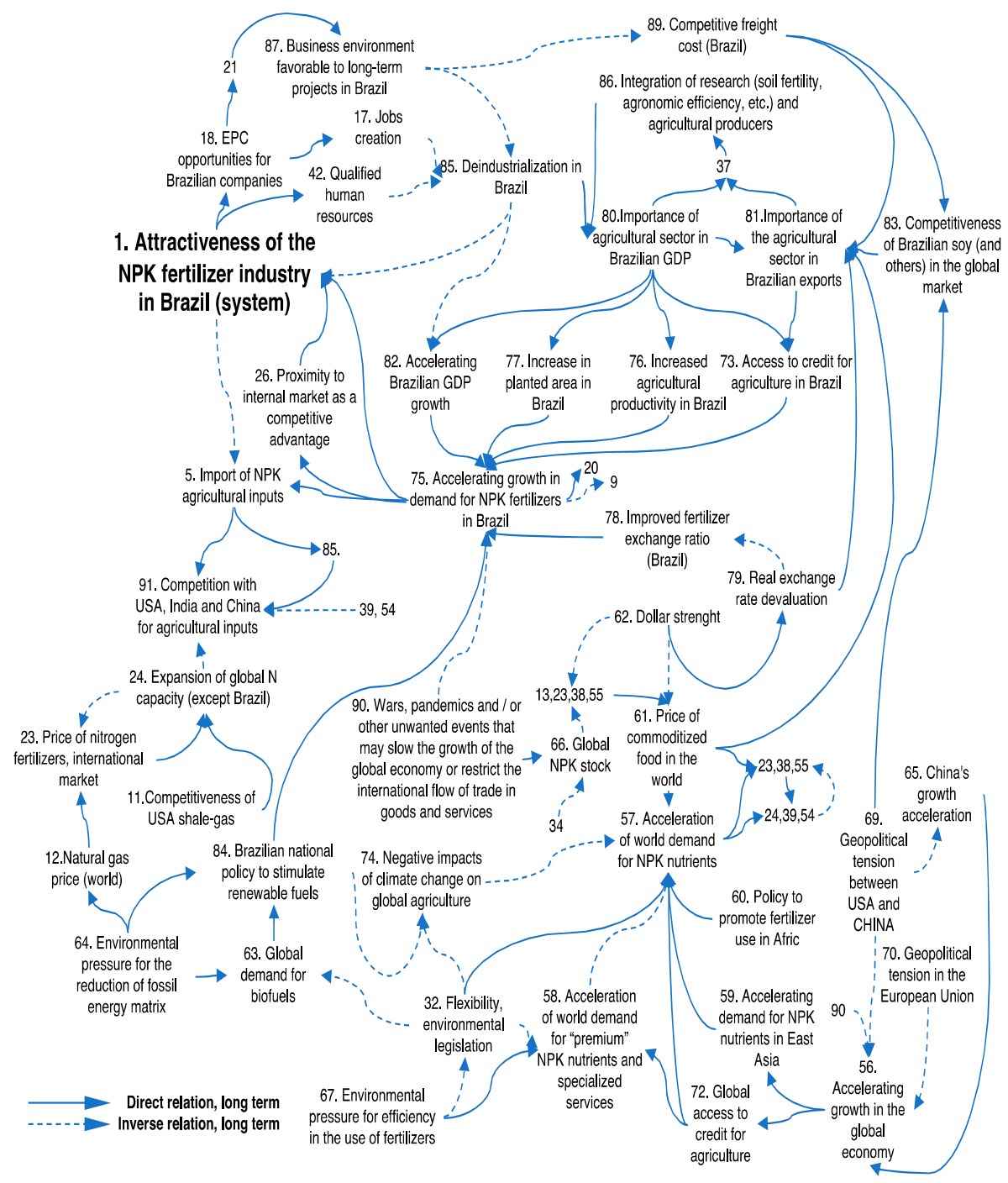

(B)

Figure 3. (A) Brazilian Fertilizer Industry Cause-Effect Map. (B) Brazilian Fertilizer Industry Cause-Effect Map.

The attractiveness of the Brazilian NPK fertilizer industry is determined by variables that affect the attractiveness of the nitrogen, phosphate, and potassium industries. One decisive factor in attracting investments for the Brazilian nitrogen fertilizer industry is the availability of natural gas at competitive prices. The withdrawal of Petrobras from the fertilizer market could impair its attractiveness, because although it reduces industrial concentration in the Brazilian market, it could end up fostering increased industrial concentration on a global scale and could even jeopardize Brazilian supply. In the phosphate and potash industry, much of Brazil's competitiveness is limited by production factors, such as access to raw materials and mineral processing technologies, as well as safety and environmental regulation issues. Government efforts to improve the mining business environment might be an advantage in the future. There are local production factors that affect the entire NPK fertilizer industry, such as the defective logistics infrastructure and the cost of energy. The exemption of import tariffs for fertilizers is favorable for agribusiness (a very influential industry in Brazil), but it creates hindrances to the national fertilizer industry.

Globally, there is already a high level of idle capacity, which makes new players less inclined to invest in Brazil. The global industry concentration has a similar effect: Why would any company start a 
new venture if they already have idle capacity elsewhere? Brazil has been increasingly deindustrialized in recent years, shrinking the size of its industrial capacity, and impairing the synergy and density of some production chains, fertilizers included. From the perspective of demand, the growing importance of Brazilian agribusiness (e.g., the Renovabio initiative) could provide opportunities for the national fertilizer industry. China may boost this demand with grains and meat. The proximity of the Brazilian consumer market could be an advantage for the attractiveness of its fertilizer industry. In a wide context, accelerated global economic growth tends to increase the demand for fertilizers. Factors such as a weaker dollar, increased demand for biofuels, higher prices (and smaller inventories) of agricultural commodities, increased per capita income in developing economies, global access to agricultural credit and fertilizer subsidy schemes tend to boost the demand for NPK fertilizers, which means this industry is likely to become more profitable worldwide.

\section{Results and Discussion}

Nine specific events with a significant impact on the attractiveness of the Brazilian fertilizer industry were devised by the authors (in a brainstorming session, with the help of Figure 3) and presented to 38 experts (Table 1). The Delphi Questionnaire survey data were collected in May and June 2020 and the following observation was added to the questionnaire: "The ongoing pandemic caused by COVID-19 might cause profound changes in society in a variety of aspects (e.g., beliefs and values, political, institutional, economic, social, military, environmental, scientific and technological issues). In the case of a prospective study ranging until 2035, this event cannot be disregarded: the pandemic may cause structural changes, and not just circumstantial ones. However, the answers to the questionnaire should not only reflect the current situation, because it is a long-term prospective study." A total of 512 scenarios have been generated (combinations of nine binary events), which were ordered by probability. Four of these scenarios (Figure 4) were featured for more in-depth analysis.

The threats facing the development of the Brazilian fertilizer industry have to do with the occurrence of events 1,2,3, and 6 and the non-occurrence of events 8 and 9. Event 5 constitutes the biggest opportunity, while events 4 and 7 are moderate opportunities-preactive analysis. The target scenario selected is the second most likely scenario, which differs from the most likely scenario according to the unconditional occurrence of event 9-proactive analysis (see Table 2).

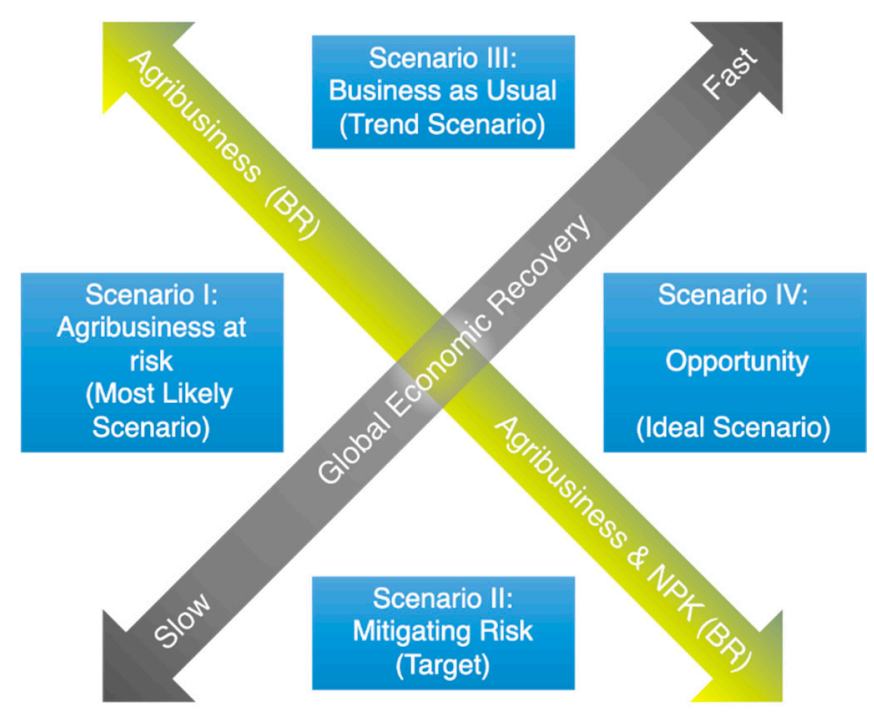

Figure 4. Brazilian Fertilizer Industry Scenarios in 2035. 


\subsection{Scenario I: Agribusiness at Risk (Most Likely Scenario)}

According to the experts' responses, the scenario "Agribusiness at Risk (most likely scenario)" is associated with an environment of low or moderate global economic growth until 2035 (less than $2.5 \%$ p.a.). The balance of powers prevailing at the end of the 2010 s, followed by factors prompted (or aggravated) by the pandemic at the beginning of the 2020s, curb global economic growth (especially in emerging and developing countries) for some 15 years. Thenceforth, a resumption of global economic growth is more likely. China-the powerhouse of the global economy for a long time-sees modest GDP growth in this period (less than 5\% p.a.). While it is self-sufficient in NPK fertilizers today (importing and exporting little, with some seasonal variations), it could increase its imports considerably by 2035 .

The slowdown in demand for commodities means their prices cannot be kept at attractive levels for exporter countries. Nonetheless, food commodity prices suffer less than those of industrial commodities. Fertilizer prices also remain at low and moderate levels, especially in the early 2020s. As such, the impacts of the availability and cost of the main agricultural inputs (like fertilizers) in the early years are not so significant in Brazil, seasonal effects aside. However, food commodity producers who see their currencies lose value in this context of low economic growth are harder hit by the cost of agricultural inputs (especially when these are for internal consumption). In this same scenario, the global availability of credit becomes an obstacle to major investments and new projects, constraining the restructuring of different global value chains, such as fertilizers. Furthermore, this limited availability of credit affects farming, reducing demand for NPK fertilizers.

Table 1. Events and Delphi Questionnaire.

\begin{tabular}{|c|c|c|}
\hline Event & Question & Average Result (2 Rounds) \\
\hline 1-Slowdown in global economic growth & $\begin{array}{l}\text { How likely is it that, until 2035, there will be } \\
\text { an overall slowdown in the growth of the } \\
\text { global economy (rates below } 2.5 \% \text { growth } \\
\text { in 2020-2035)? }\end{array}$ & $55.09 \%$ \\
\hline 2-Slowdown in China's GDP growth & $\begin{array}{c}\text { How likely is it that by } 2035 \text { Chinese GDP } \\
\text { growth will have slowed (rates below } 5.0 \% \\
\text { growth per year in 2020-2035)? }\end{array}$ & $61.99 \%$ \\
\hline $\begin{array}{l}\text { 3-Maintenance of moderate prices, } \\
\text { food commodities }\end{array}$ & $\begin{array}{l}\text { How likely is that the main food } \\
\text { commodities will largely remain at } \\
\text { moderate prices until 2035? }\end{array}$ & $56.91 \%$ \\
\hline $\begin{array}{l}\text { 4-Reduction in the participation of } O \& G \\
\text { in the world energy matrix }\end{array}$ & $\begin{array}{l}\text { How likely is it that by } 2035 \text { the global } \\
\text { energy market will have reduced its } \\
\text { dependence on the O\&G industry (currently } \\
\text { around } 58 \% \text {, accounting for oil and natural } \\
\text { gas) to } 45 \% \text { or less? }\end{array}$ & $62.15 \%$ \\
\hline $\begin{array}{l}\text { 5-Increase in biofuel consumption by the } \\
\text { Brazilian transportation sector }\end{array}$ & $\begin{array}{l}\text { How likely is that by } 2035 \text { biofuels } \\
\text { (biodiesel and ethanol) will provide } 30 \% \text { (or } \\
\text { more) of the fuel needs of the transport } \\
\text { sector in Brazil? }\end{array}$ & $64.16 \%$ \\
\hline $\begin{array}{l}\text { 6-Increase in mergers and acquisitions in } \\
\text { the global NPK fertilizer industry }\end{array}$ & $\begin{array}{l}\text { How likely is that there will be an increase } \\
\text { in the number of mergers and acquisitions } \\
\text { in the global industry of production of } \\
\text { essential inputs for the agribusiness chain } \\
\text { (NPK fertilizers) until 2035? }\end{array}$ & $64.33 \%$ \\
\hline $\begin{array}{l}\text { 7-Increase in gross value of agricultural } \\
\text { production in Brazil }\end{array}$ & $\begin{array}{l}\text { How likely is that by } 2035 \text { the gross value of } \\
\text { agricultural production (considering only } \\
\text { crops) will have shown (predominantly) } \\
\text { average annual growth of more than } 6 \% \text { per } \\
\text { year in the last } 15 \text { years? }\end{array}$ & $54.52 \%$ \\
\hline $\begin{array}{l}\text { 8-Increased share of the manufacturing } \\
\text { industry in Brazilian GDP }\end{array}$ & $\begin{array}{l}\text { How likely is that by } 2035 \text { the Brazilian } \\
\text { manufacturing industry will again account } \\
\text { for at least } 20 \% \text { of GDP? }\end{array}$ & $44.82 \%$ \\
\hline $\begin{array}{l}\text { 9-Government incentives (tax, credit, or } \\
\text { other) for the fertilizer industry in Brazil }\end{array}$ & $\begin{array}{c}\text { How likely is it that until } 2035 \text { the Brazilian } \\
\text { government will have created tax, credit or } \\
\text { other forms of incentives for the fertilizer } \\
\text { industry in Brazil? }\end{array}$ & $47.76 \%$ \\
\hline
\end{tabular}


Table 2. Reference Scenarios, Preactive Analyses, Proactive Analysis.

\begin{tabular}{|c|c|c|c|c|c|}
\hline Event & $\begin{array}{l}\text { Most Likely } \\
\text { Scenario }\end{array}$ & Ideal Scenario & Trend Scenario & $\begin{array}{c}\text { Event } \\
\text { Classification }\end{array}$ & $\begin{array}{l}\text { Target } \\
\text { Scenario }\end{array}$ \\
\hline $\begin{array}{l}\text { 1-Slowdown in global } \\
\text { economic growth }\end{array}$ & Occurs & Does not occur & Does not occur & $\begin{array}{l}\text { Moderate threat, } \\
\text { change in trend }\end{array}$ & Occurs \\
\hline $\begin{array}{l}\text { 2-Slowdown in China's } \\
\text { GDP growth }\end{array}$ & Occurs & Does not occur & Does not occur & $\begin{array}{l}\text { Moderate threat, } \\
\text { change in trend }\end{array}$ & Occurs \\
\hline $\begin{array}{l}\text { 3-Maintenance of moderate } \\
\text { prices for food commodities }\end{array}$ & Occurs & Does not occur & Occurs & $\begin{array}{l}\text { Strong threat, no } \\
\text { change in trend }\end{array}$ & Occurs \\
\hline $\begin{array}{l}4 \text {-Reduction in the } \\
\text { participation of O\&G in the } \\
\text { world energy matrix }\end{array}$ & Occurs & Occurs & Does not occur & $\begin{array}{c}\text { Moderate } \\
\text { opportunity, } \\
\text { change in trend }\end{array}$ & Occurs \\
\hline $\begin{array}{l}\text { 5-Increase in biofuel } \\
\text { consumption by the Brazilian } \\
\text { transportation sector }\end{array}$ & Occurs & Occurs & Occurs & $\begin{array}{l}\text { Strong opportunity, } \\
\text { no change in trend }\end{array}$ & Occurs \\
\hline $\begin{array}{l}\text { 6-Increase in mergers and } \\
\text { acquisitions in the global NPK } \\
\text { fertilizer industry }\end{array}$ & Occurs & Does not occur & Occurs & $\begin{array}{l}\text { Strong threat, no } \\
\text { change in trend }\end{array}$ & Occurs \\
\hline $\begin{array}{l}\text { 7-Increase in the gross value } \\
\text { of agricultural production } \\
\text { in Brazil }\end{array}$ & Occurs & Occurs & Does not occur & $\begin{array}{c}\text { Moderate } \\
\text { opportunity, } \\
\text { change in trend }\end{array}$ & Occurs \\
\hline $\begin{array}{l}\text { 8-Increased share of the } \\
\text { manufacturing industry in } \\
\text { Brazilian GDP }\end{array}$ & Does not occur & Occurs & Does not occur & $\begin{array}{l}\text { Strong threat, no } \\
\text { change in trend }\end{array}$ & Does not occur \\
\hline $\begin{array}{l}\text { 9-Government incentives } \\
\text { (tax, credit or other) for the } \\
\text { fertilizer industry in Brazil }\end{array}$ & Does not occur & Occurs & Does not occur & $\begin{array}{l}\text { Strong threat, no } \\
\text { change in trend }\end{array}$ & Occurs \\
\hline
\end{tabular}

Energy is cheaper in the early years of the 2020s thanks to low O\&G prices. By 2035, however, prices are back to profitable levels for the main global players. O\&G accounts for less of the global energy mix by 2035 (shifting from $58 \%$ of global energy to less than $45 \%$ ). Many companies from this sector perceive this and over this 15-year period invest in diversifying their portfolio. Societal pressure for less $\mathrm{CO}_{2}$-emitting energy sources, vehicle electrification (initially more in developed countries, then spreading around the world), accelerated development of hydrogen technologies, expanded production of biofuels in countries like Brazil and the USA, more widespread use of solar and wind power, and the development of circular economy business models combine to reduce the share of O\&G in the global energy mix. This change could have been more abrupt, but China reduces its coal consumption and considerably increases its $O \& G$ consumption. At the same time, governments and businesses see a new opportunity: the use of natural gas as a raw material (rather than as a source of energy), adding more value to production chains, and causing fewer environmental impacts. Some countries make natural gas a prime raw material (but not Brazil). The main global fertilizer companies start to operate with less exposure to risk in the cost of this input (especially the producers of nitrogen fertilizers), but the Brazilian fertilizer industry becomes less attractive as the country fails to invest in its natural gas infrastructure. Brazil seizes the opportunity to reconfigure its energy mix and its biofuel market expands. Biofuels now account for over $30 \%$ of the fuels used by the domestic transportation sector.

Low fertilizer commodity prices, stronger supply than demand, global idle capacity, smaller agricultural profit margins, limited availability of agricultural credit, and reduced per capita income in developing countries (and other events) prompt the leading global fertilizer producers to set up strategic alliances (e.g., mergers) to maintain their installed capacity (or even just to survive) in this challenging scenario, which lasts for ten years.

Brazil's agribusiness production and exports become a larger share of the country's GDP and trade balance (annual growth rates above 6\%). As of 2020, with the potential to reorganize foreign trade relations (thanks to geopolitical events such as the dispute between the USA and China), Brazil steps into the breach to export more. 
By 2035, Brazil has not undergone any reindustrialization, and is recording small, incremental GDP increases. The business environment for industry is still of limited attractiveness. Even with the slowdown in competition from Chinese industry, the lack of investment in infrastructure (especially logistics and energy) and political and economic instability prevent any significant increase in the country's industrial capacity. Government and industry fail to work in unison to boost the country's NPK fertilizer production capacity. Its nitrogen fertilizer production capacity shrinks (remaining below its 2017-2018 production level), phosphate fertilizer production stagnates, and the only potassium mine still in operation is depleted. In 2035, Brazil is importing over $85.5 \%$ of its fertilizer needs (around 52.5 million tons of NPK).

By 2035, the global economy is starting to look up. Demand for Brazil's agricultural products is growing (agricultural commodities prices are rising). Countries like the USA, India and Brazil (and perhaps China) are vying for the fertilizers available on the world market. Brazil and India are in a more vulnerable position than the USA and China in this respect. NPK fertilizers are overpriced and have started to cause geopolitical disputes. The Brazilian agribusiness (food and energy) profit margin is in jeopardy. The government starts to wonder about its fertilizer production capacity.

\subsection{Scenario II: Mitigating Risk (Target)}

What distinguishes scenario II from scenario I is that event 9 (Government incentives for the fertilizer industry in Brazil) takes place. In other words, this scenario is based on the assumption of a pro-active stance. In the first few years of the 2020s, the global and local environments are not attractive to new projects to expand Brazilian fertilizer production. Many old production plants are close to shutting their doors in this period: it is cheaper to import. Generally, Brazilian industrial conditions are no more favorable. The supply of natural gas improves in terms of availability and price, but its competitiveness is still limited. However, aware of the potential risks to Brazilian agriculture in the future environment, the government designs a strategic plan to boost this sector in the country. The first step is to encourage existing businesses to maintain their installed capacity. From 2022 to 2026, fertilizer companies are given tax breaks for the acquisition and importing of machinery, equipment, instruments, and construction materials for their plants or to incorporate into new projects as part of the Fertilizer Industry Infrastructure Development Plan. In counterpart, these companies are required to invest in infrastructure sharing (transportation, steam, energy, utilities) or process sharing (integration with other industries, e.g., channeling waste from the potassium fertilizer industry as an input for chlorine and caustic soda production). Tax parity between national and imported fertilizers is partially promoted: the National Congress is sensitive to the national fertilizer industry, but the agribusiness lobby blocks any moves to raise taxes on imported inputs. In response, the national nitrogen fertilizer industry recoups much of its installed capacity at its existing plants. Phosphate fertilizer production grows $25 \%$ in this 15 -year period, and at least one production expansion project (equivalent to the Carnalita or Autazes plants in size) takes place, raising the supply of potassium chloride to one million tons per year. Demand for fertilizers in 2035 is around 52.5 million tons, and imported fertilizers account for around $78.3 \%$ of this value, since NPK fertilizer production has grown by around $40 \%$ between 2017 and 2035.

In 2035, the global economy is healthy. Demand for Brazil's agribusiness (food and energy) products is high and growing (prices are high). Brazilian manufacturing has lost ground in this 15-year period. Countries like the USA, India and Brazil (and perhaps China) are vying for the fertilizers available on the world market. Brazil and India are in a more vulnerable position than the USA and China in this respect. NPK fertilizer prices rise further and become the target of geopolitical disputes. This new cycle of improved fertilizer production attractiveness, commencing in 2035, enables new projects, and Brazil, which has incrementally expanded its installed fertilizer production capacity from 2020 to 2035, is more attractive for the expansion of this industry and capable of receiving new projects (whether brownfield or greenfield). 


\subsection{Scenario III: Business as Usual (Trend Scenario)}

The Business as Usual scenario constitutes a straightforward extrapolation of existing trends. Despite the downward trend seen in global economic growth in the last decade (culminating in growth of just $2.4 \%$ in 2019 and aggravated by the COVID-19 pandemic), the twentieth century teaches us that it is rare for a global economic crisis to last for 15 years. As such, recuperation is expected in the coming years. From this perspective, it is expected that China will soon return to the growth rates that prevailed in the last 30 years.

Especially in the early 2020s, food commodities tend to remain at low prices. Prices gradually become more attractive as the global economy starts to pick up. Food commodity exporters with more solid economies (e.g., the USA) will probably take a larger market share. Developing exporters of these commodities, hard hit in the early years of the 2020s, gradually get the resources they need to compete on the global market and get back on track.

Although O\&G are already set to account for less of the world energy mix by 2035, the transition from the current status, where they account for $58 \%$ of all primary energy sources, to below $45 \%$ will only be seen a few years later. The dip in crude prices seen as of January 2020 temporarily puts the brakes on several alternative energy projects. Nonetheless, the use of biofuels in Brazil continues to grow until 2035, when biodiesel and ethanol account for over $30 \%$ of the energy consumed by the transportation sector. The government's Renovabio program and low food commodity prices (especially in the early 2020s) have a positive impact on this scenario, offsetting the effects of low oil prices. This transition in the transportation sector is virtually null (or even recedes) between 2020 and 2024, when the Brazilian sugar and ethanol industry has trouble coping with the low oil prices.

More mergers and acquisitions are seen in the global fertilizer industry. Despite the prospects for improved demand conditions in the coming years, production factors, such as limited availability of raw materials at competitive prices, have a determining impact. Companies operating in the links of the chain that are closest to mining and extraction and companies operating closer to the consumer market forge stronger strategic alliances until 2035. The overwhelming strategy of commoditization (instead of investing in new differentiated products and service provision) favors economies of scale. The idle capacity accumulated globally in recent years makes it hard for new players to enter the sector.

The importance of agribusiness to the Brazilian economy continues to grow at rates above the global average. However, the gross agricultural output (crops) will not reach annual growth rates of $6 \%$ between 2020 and 2035, averaging around 4\%. In the early years after 2020, low food prices, limited investments in logistics infrastructure, and restricted access to credit squeeze sector growth. Potential economic turbulence in Brazil puts the brakes on domestic consumption. The Brazilian manufacturing industry behaves as described in Scenario I, remaining of limited attractiveness.

Government and industry fail to work in unison to boost the country's NPK fertilizer production capacity. Its installed nitrogen fertilizer production capacity shrinks, phosphate fertilizer production stagnates, and the only potassium mine still in operation is depleted. In 2035, Brazil is importing around $84.5 \%$ of its fertilizer needs (around 49.2 million tons).

By 2035, the global economy is at full throttle. Demand for Brazilian agricultural output is high. Brazil's manufacturing industry has lost importance in this 15 -year period. Countries like the USA, India and Brazil (and perhaps China) are vying for the fertilizers available on the world market. Brazil and India are in a more vulnerable position than the USA and China in this respect. NPK fertilizer prices are rising and have become a cause of geopolitical tensions. Agribusiness (food and energy) fertilizer supply is at risk, but at less risk than in Scenario I, because national demand for fertilizers has grown at lower rates.

\subsection{Scenario IV: Opportunity (Ideal Scenario)}

The Opportunity (or Ideal) Scenario occurs in the context of rapid recovery of the global economy after 2020. Even after a decade of economic slowdown (since the 2008 global financial crisis) and the COVID-19 pandemic, the global business environment is quick to regain confidence. In 2024, 
the economy is more vigorous than it was in 2019. China, Russia, Brazil, and India are key players in this economic turnabout. By 2025, commodity exports are again at high levels, but less so than in the 2000s. These high prices enable many exporting countries (like Brazil) to adjust their balance of payments after the pandemic. This foreign trade income gives Brazil the chance to make a series of investments in infrastructure and productivity. China develops closer trade ties with Brazil, even financing investments in infrastructure.

The global O\&G market has similar behavior to what is described in scenarios I and II. What is different, however, is that Brazil's natural gas value chain is restructured: by 2030, Brazil's natural gas is more competitive, and natural gas has started to be prized as a raw material in Brazil, thanks to tax and fiscal incentives (more value is added to the pre-salt reserves). The country's fertilizer producers are able to operate with less exposure to natural gas price oscillations. Biofuels are responsible for over 30\% for the fuel used by the country's transportation sector. Developed countries with biofuel blending mandates start to import biodiesel from Brazil at high prices. This boosts Brazilian demand for NPK fertilizers.

The global economic recovery proves a watershed for the global fertilizer industry. Strong demand means profit margins-squeezed for many years-become healthier. Expansion projects abandoned between 2008 and 2019 begin to get off the drawing board. The COVID-19 pandemic prompts the big players in the sector to review their strategy: reliability becomes more important and companies tend to channel their investments into projects that involve a diminished physical distance between the different links in their production chains (nearshoring). Proximity to the agricultural consumer market (like Brazil) becomes the object of disputes between these companies. With increasingly stringent environmental legislation, it may be necessary to boost the performance of (and add more value to) fertilizers. New projects (especially phosphate and potash mining) tend to come up against more environmental and security-related legislation hurdles. This prompts demand for premium fertilizers, like controlled release fertilizers and fertilizers with reduced levels of leaching, both of which offer chances for a higher profit margin. Investments in new process technologies (alternative sources of phosphate and potassium, mining of tailings, etc.) make new, previously overlooked projects feasible. Furthermore, crop nutrition consultancy services provide another potential income stream for this industry. While this environment is favorable for the expansion of players that are already established on the market (and verticalization strategies), it also attracts new players, boosting competition and reducing the global concentration of the sector. Idle installed capacity is reduced, as are global fertilizer inventories.

As of 2020, with a reorganization of international trade relations (prompted by the US-China geopolitical dispute, among other events), Brazil steps into the breach to export more foodstuffs. The COVID-19 pandemic has a radical impact on China's food production practices: much of its meat production was not channeled into the animal feed market. Brazil's exports of soy and corn to the country increase. Its meat exports also rise, because the Chinese government decides to dilute the public health risk inherent to its attempt to supply its whole domestic market with animal protein (which boosts Brazil's corn and soy output). Brazil's agribusiness (food and energy), which grows at over $6 \%$ a year in these 15 years, enables a readjustment of the balance of payments and investments to be made in logistics infrastructure. Keen to innovate, agribusiness increases its productivity and reduces its planted area in Brazil, resulting in increased demand for fertilizers. There is synergy between the sector and R\&D institutions. Indeed, Brazil learns to exploit its biodiversity more effectively, and, as of 2035 , its agribusiness no longer sees biodiversity as a barrier, but as an opportunity to add value to its products.

In the same 15-year period, Brazil executes a robust strategic plan to boost the competitiveness of its domestic industry, and by 2030 it is beginning to reap the rewards. The 2020 pandemic marked the beginning of policies to reduce the concentration of global industry and initiate its migration away from Asian countries. With Brazil enjoying economic and political stability just a few years after the outbreak of the COVID-19 pandemic, global businesses now see Brazil for its full potential: not only a source of 
natural resources and a potentially vibrant domestic market, but also a way of enhancing the reliability of the supply of global value chains. A substantial investment plan leads to improved port, airport, and road infrastructure. Plans are also made to restructure the country's railroad network. Little has yet left the drawing board, but prospects for 2050 are looking good. With increased competition in the Brazilian natural gas market as of 2021, there is greater availability of this resource in Brazil at competitive prices by 2030. In this strategic plan, the fertilizer industry is considered strategic, as are the fine chemicals, drug, bioproducts, and agricultural machinery industries, among others. The 2025 tax reform reduces bureaucratic (and litigation) costs in the country, while also curbing inter-state bickering over investments, as the competitive advantages intrinsic to each region of Brazil are prioritized. Fertilizer businesses are given incentives as in scenario II; however, now, the Brazilian business environment is more attractive to new ventures. As a result, the installed capacity for nitrogen fertilizers in Brazil is boosted (and there is also a new large ammonia and urea plant), the phosphate fertilizer industry's output expands by $50 \%$, and two new large-scale projects for potassium chloride production go into service.

In 2035, demand for fertilizers stands at around 52.5 million tons, $29.6 \%$ of which Brazilian industry is capable of supplying. The USA, India and Brazil (and perhaps China) are vying for the fertilizers available on the world market. However, this dispute is less exacerbated than in scenarios I and II because in recent years the global fertilizer industry has expanded its installed capacity. By 2035, Brazil runs little risk of a supply shortage for its agricultural activities: the production factors are propitious for the expansion of the Brazilian fertilizer industry's output.

\section{Conclusions}

The use of prospective scenarios proved effective for identifying potential challenges and opportunities the Brazilian fertilizer industry could face in the long term. The pre-active analysis demonstrated that this industry should be prepared for a scenario of limited increase in demand on a global scale. Furthermore, low prices in the agricultural market may squeeze the profit margins of the sector in the early years of the 2020s. The global fertilizer industry is likely to hamper the entry of new businesses to the sector and strategic alliances will be forged to maintain existing installed capacity. The reduced importance of oil in the overall energy mix is an opportunity that should be seized: it could be more widely available for use as a raw material, which could be positive for the nitrogen fertilizer industry. In Brazil, growth of the biofuel market and agricultural output are opportunities that should be harnessed.

Should de-industrialization continue to be seen in Brazil, and should the Brazilian government fail to provide any stimulus for the country's fertilizer industry, it is likely that by 2035 , the country will be importing over $85 \%$ of its fertilizers (and even more for nitrogen and potassium fertilizers). By 2035, Brazil's biofuel industry sector would be overexposed to price conditions and availability on the global fertilizer market-biofuels can lose competitiveness. The COVID-19 pandemic poses the biofuel industry with a serious threat, since it exacerbates the global downward trend in the attractiveness of NPK fertilizer production in the early years of the 2020s, in addition to momentarily reducing competitiveness vis-à-vis other fossil energy sources.

Author Contributions: Conceptualization, P.I.V.F., E.F. and A.M.d.S.A.; formal analysis, P.I.V.F.; investigation, P.I.V.F., E.F., A.L.C.d.C. and A.M.d.S.A.; methodology, P.I.V.F., E.F. and R.J.d.S.G.; project administration, P.I.V.F.; software, P.I.V.F. and R.J.d.S.G.; supervision, E.F., A.L.C.d.C. and A.M.d.S.A.; validation, A.M.d.S.A.; visualization, R.J.d.S.G.; writing — original draft, P.I.V.F.; writing-review and editing, E.F. and A.M.d.S.A. All authors have read and agreed to the published version of the manuscript.

Funding: This research received no external funding.

Conflicts of Interest: The authors declare no conflict of interest. 


\section{References}

1. MAPA AGROSTAT. Foreign Trade Statistics-Ministry of Agriculture, Livestock and Supply of Brazil. Available online: http://indicadores.agricultura.gov.br/agrostat/index.htm (accessed on 2 June 2020).

2. MAPA. Gross Value of Agricultural Production in 2019-Ministry of Agriculture, Livestock and Supply of Brazil. Available online: http://antigo.agricultura.gov.br/noticias/vbp-e-estimado-em-r-683-2-bilhoes-para2020/copy_of_202002ValorBrutodaProduoPrincipaisProdutosAgropecurios.xlsx (accessed on 25 May 2020).

3. IFA IFASTAT. Comsumption Report. Available online: https://www.ifastat.org/ (accessed on 1 June 2020).

4. Hijbeek, R.; Van Loon, M.; Van Ittersum, M.K. Fertiliser Use and Soil Carbon Sequestration; CGIAR Research Program on Climate Chang, Agriculture and Food Security: Wageningen, The Netherlands, 2019; Volume 5.

5. Burney, J.A.; Davis, S.J.; Lobell, D.B. Greenhouse gas mitigation by agricultural intensification. Proc. Natl. Acad. Sci. USA 2010, 107, 12052-12057. [CrossRef] [PubMed]

6. IFA. Agenda 2030—Plant Nutrients and Climate Action. Available online: https://www.fertilizer. org/Public/Stewardship/Publication_Detail.aspx?SEQN=5854\&PUBKEY=F8D6C582-AA17-4A43-BF3143B36E10C236 (accessed on 3 August 2020).

7. De Souza, L.M.; Mendes, P.; Aranda, D. Assessing the current scenario of the Brazilian biojet market. Renew. Sustain. Energy Rev. 2018, 98, 426-438. [CrossRef]

8. EPE. Brazilian Energy Balance 2019-Year 2018; EPE: Rio de Janeiro, Brazil, 2019.

9. BP. Statistical Review of World Energy 2018; BP: London, UK, 2019.

10. EPE. National Energy Balance-Synthesis Report. Available online: https://www.epe.gov.br/sites-pt/ publicacoes-dados-abertos/publicacoes/PublicacoesArquivos/publicacao-479/topico-521/RelatórioSínteseBEN 2020-ab2019_Final.pdf (accessed on 29 July 2020).

11. Brasil Law 13.576, 26 December 2017 (Renovabio). Available online: http://www.planalto.gov.br/ccivil_03/ _ato2015-2018/2017/lei/L13576.htm (accessed on 31 July 2020).

12. Ministry of Mines and Energy. Reunião da Câmara Setorial do Biodiesel. 7 June 2018. Available online: https://www.gov.br/agricultura/pt-br/assuntos/camaras-setoriais-tematicas/documentos/camarassetoriais/oleaginosas-e-biodiesel/2018/33a-ro/apresentacao-renovabio-camara-setorial-biodiesel.pdf (accessed on 29 July 2020).

13. ANDA. Setor de Fertilizantes-Anuário Estatístico de 2018, 1st ed.; Associação Nacional para Difusão de Adubos (ANDA): São Paulo, Brazil, 2019.

14. COMEXTAT. Statistics from the Brazilian Foreign Trade Secretary. Available online: http://comexstat.mdic. gov.br/pt/home (accessed on 28 July 2020).

15. Fernandes, F.R.C.; Kulaif, Y. Panorama dos agrominerais no Brasil: Atualidades e perspectivas. In Agrominerais para o Brasil; Fernandes, F.R.C., da Luz, A.B., Castilhos, Z.C., Eds.; CETEM: Rio de Janeiro, Brazil; MCT: Rio de Janeiro, Brazil, 2010; pp. 1-20. ISBN 9788561121617.

16. Ramirez, R.; Selsky, J.W.; van der Heijden, K. Business Planning for Turbulent Times, 1st ed.; Ramirez, R., Selsky, J.W., van der Heijden, K., Eds.; Earthscan: London, UK, 2010, ISBN 978-1-84407-567-6.

17. Popper, R. How are foresight methods selected? Foresight 2008, 10, 62-89. [CrossRef]

18. Godet, M. Future memories. Technol. Forecast. Soc. Chang. 2010, 77, 1457-1463. [CrossRef]

19. Schoemaker, P.J.H. Forecasting and scenario planning: The challenges of uncertainty and complexity. In Blackwell Handbook of Judgment and Decision Making; Blackwell Publishing Ltd.: Malden, MA, USA, 2008; pp. 274-296, ISBN 9781405107464.

20. Marcial, E.C.; Grumbach, R.J.D.S. Cenários Prospectivos: Como Construir um Futuro Melhor, 5th ed.; FGV Editora: Rio de Janeiro, Brazil, 2008; ISBN 9788522506880.

21. Marchais-Roubelat, A.; Roubelat, F. The Delphi method as a ritual: Inquiring the Delphic Oracle. Technol. Forecast. Soc. Chang. 2011, 78, 1491-1499. [CrossRef]

22. Ringland, G.; Young, L. Scenarios in Marketing: From Vision to Decision; John Wiley \& Sons, Inc.: Chichester, UK, 2015; ISBN 9780470666265.

23. FIESP. Outlook FIESP 2029—Projections for the Brazilian Agribusiness; FIESP: São Paulo, Brazil, 2020; ISBN 978-65-5786-001-04.

24. de Miranda, R.A.; Duraes, F.O.M.; Garcia, J.C.; Parentoni, S.; Santada, D.P.; Purcino, A.A.C.; de Alves, E.R.A. Supersafra de milho e o papel da tecnologia no aumento da produção. Rev. Política Agrícola 2019, 1, 149-150. 
25. CONAB. Acompanhamento da safra brasileira 2019/2020. In Acompanhamento da Safra Brasileira de Grãos 2019/2020; CONAB: Brasília, Brazil, 2020; Volume 7, pp. 1-74.

26. CONAB. Planilhas de Custos de Produção-Culturas de 1 a Safra. Available online: https://www.conab.gov.br/info-agro/custos-de-producao/planilhas-de-custo-de-producao/itemlist/ category/406-planilhas-de-custos-de-producao-culturas-de-1-safra (accessed on 30 July 2020).

27. CONAB. Planilhas de Custos de Produção-Culturas de 2 a Safra. Available online: https://www.conab.gov.br/info-agro/custos-de-producao/planilhas-de-custo-de-producao/itemlist/ category/404-planilhas-de-custos-de-producao-culturas-de-2-safra (accessed on 30 July 2020).

28. CONAB. Planilhas de Custos de Produção-Culturas Semiperenes. Available online: https://www.conab.gov. br/ info-agro/custos-de-producao/planilhas-de-custo-de-producao/itemlist/category/407-planilhas-de-custos-deproducao-culturas-semi-perenes (accessed on 30 July 2020).

29. FAO. Lessons from the world food crisis of 2006-08. In The State Food Insecurity in the World; FAO: Rome, Italy, 2011; Volume 2008, pp. 21-31.

30. CETEM. Mineraldata from Ministry of Science and Technology (Brazil). Available online: http://mineraldata. cetem.gov.br/mineraldata/app/* (accessed on 20 July 2020).

31. ANDA. III Congresso Brasileiro de Fertilizantes-Indústria Nacional de Matéria Prima para Fertilizantes: Investimentos 2013 a 2018. Available online: http://anda.org.br/wp-content/uploads/2018/10/Investimentos_ Rodolfo_Galvani.pdf (accessed on 30 July 2020).

32. IFA. Fertilizer Outlook 2016-2020; IFA: Paris, France, 2016; pp. 21-23.

33. IFA. Fertilizer outlook 2018-2022. In Proceedings of the 86th IFA Annual Conference Production \& International Trade and Agriculture Services, Berlin, Germany, 18-20 June 2018; pp. 1-8.

34. IFA. Short-Term Fertilizer Outlook; IFA: Paris, France, 2018; pp. 26-28.

35. IFA. Short-Term Fertilizer Outlook. Available online: https://www.ifastat.org/market-outlooks (accessed on 30 July 2020).

36. Word Bank Group. Global Economic Prospects-SLow Growth, Policy Challenges. Available online: https://openknowledge.worldbank.org/handle/10986/2140 (accessed on 31 July 2020).

37. IFA. COVID-19 Implications for the Fertilizer Industry. Available online: https://www.arabfertilizer.org/ news/item/id/215 (accessed on 31 July 2020).

38. Globalfert Outlook 2020. Available online: https://globalfert.com.br/pdf/outlook_globalfert2020.pdf (accessed on 31 July 2020).

39. Jank, M.S. Postface. In China-Brazil Partnership on Agriculture and Food Security; Jank, M.S., Guo, P., de Miranda, S.H.G., Eds.; Escola Superior de Agricultura “Luiz de Queiroz”, Universidade de São Paulo: Piracicaba, Brazil, 2020; ISBN 9786587391007.

40. Ministry of Mines and Energy. Boletim Mensal de Acompanhameno da Indústria de Gás Natural-Março de 2020. Available online: http://www.mme.gov.br/web/guest/secretarias/petroleo-gas-natural-e-biocombustiveis/ publicacoes/boletim-mensal-de-acompanhamento-da-industria-de-gas-natural/-/document_library_display/ M02KzA2dNdQq/view_file/1161936?_110_INSTANCE_M02KzA2dNdQq_redirect $=$ http\%25 (accessed on 30 July 2020).

41. Acron. 2018 Annual Report-Acron Group. Available online: https://www.acron.ru/en/press-center/pressreleases/200627/ (accessed on 6 May 2020).

42. PhosAgro. Integrated Report 2018-Pure Mineral for Healthy Lifes. Available online: https://www.phosagro. com/upload/iblock/604/604e741aa079745b02a0c47ca360a814.pdf (accessed on 25 May 2020).

43. Word Bank Group. Global Economic Prospects, January 2018: Broad-Based Upturn, but for How Long? Global Economic Prospects; The World Bank: Washington, DC, USA, 2018; ISBN 978-1-4648-1163-0.

44. Brasil Resolution N $N^{\circ}$ 16-24 June 2019. Available online: http://www.mme.gov.br/documents/36112/491934/1. +Resolução_CNPE_16_2019.pdf/2d2e22aa-b6d8-d939-4eab-826b117f560b (accessed on 31 July 2020).

45. Brasil National Congress Bill 6407/2013. Available online: https://www.camara.leg.br/proposicoesWeb/ fichadetramitacao?idProposicao=593065 (accessed on 31 July 2020).

46. IBRAM. Políticas Públicas para Indústria Mineral. Available online: https://portaldamineracao.com.br/wp-content/ uploads/2018/11/eleicoes-2018-politicas-publicas-para-a-industria-mineral.pdf (accessed on 31 July 2020).

47. Abram, M.B.; Bahiense, I.C.; Porto, C.G.; Brito, R.S. Projeto Fosfato Brasil, 1st ed.; Abram, M.B., Ed.; CPRM: Salvador, Brazil, 2011; ISBN 978-85-7499-125-2. 
48. Vale Formulário 20-F para o Exercício Encerrado em 31 de Dezembro de 2018. Available online: http://www.vale. com/brasil/PT/investors/information-market/annual-reports/20f/Paginas/default.aspx (accessed on 31 July 2020).

49. National Mining Agency. Sumário Mineral 2017, 1st ed.; Costa, M.M.D., Medeiros, K.A., Lima, T.M., Eds.; ANM/MME: Brasília, Brazil, 2019; Volume 37.

50. Sinprifert; Abiquim. Fertilizantes: A Busca do Produtor Nacional por Condições de Igualdade com o Produto Importado-National Congress. Available online: https://www2.camara.leg.br/atividade-legislativa/ comissoes/comissoes-permanentes/capadr/audiencias-publicas/audiencias-publicas-2015/mesa-tecnica16-de-dezembro-vale-fertilizantes (accessed on 20 July 2020).

Publisher's Note: MDPI stays neutral with regard to jurisdictional claims in published maps and institutional affiliations.

(C) 2020 by the authors. Licensee MDPI, Basel, Switzerland. This article is an open access article distributed under the terms and conditions of the Creative Commons Attribution (CC BY) license (http://creativecommons.org/licenses/by/4.0/). 